\title{
5th Annual Polish-Spanish Conference on Roman Law: "Modern Application of the Roman Law Rules" Olsztyn 23 maja 2014 r.
}

W dniu 23 maja 2014 r. w Centrum Konferencyjnym Uniwersytetu Warmińsko-Mazurskiego w Olsztynie odbyła się piąta polsko-hiszpańska konferencja poświęcona prawu starożytnego Rzymu. Tematem przewodnim spotkania było współczesne zastosowanie reguł prawa rzymskiego. Konferencję zorganizowały Katedra Prawa Rzymskiego i Porównawczego Wydziału Prawa i Administracji Uniwersytetu Warmińsko-Mazurskiego w Olsztynie i Área de Derecho Romano (Departamento de Derecho Público) Universitat Jaume I, Castellón de la Plana w Hiszpanii, przy wsparciu Studenckiego Koła Naukowego Miłośników Społeczeństw i Kultury Antyku „Romanitas” oraz Koła Prawa Rzymskiego i Porównawczego Uniwersytetu Warmińsko-Mazurskiego w Olsztynie.

Uroczystego otwarcia obrad dokonał w imieniu organizatorów dr hab. Piotr Krajewski, prof. UWM i prodziekan Wydziału Prawa i Administracji olsztyńskiej uczelni. Następnie słowa powitania do wszystkich uczestników konferencji skierowali prof. dr hab. Bronisław Sitek (UWM) oraz goście przybyli z hiszpańskiego ośrodka naukowego Universitat Jaume I, prof. dr. Carmen Lázaro Guillamón i dr. Andrea Planchadell Gargallo.

Pierwszą sesję, nad której przebiegiem czuwał prof. dr hab. Bronisław Sitek otworzył swoim wystąpieniem prof. dr hab. Witold Wołodkiewicz (Uniwersytet Warszawski), La regole giuridiche latine nella pratica giudiziaria e architettura polacca. Kolejne prelekcje w tej części obrad wygłosili: prof. dra. Carmen Lázaro Guillamón (Universitat Jaume I), The exempla concerning silence set out in the gl. Qui tacet, ad. D. 50. 17. 42; prof. dr hab. Bronisław Sitek, In dubio magis contra fiscum est respondendum (D. 49. 14. 10); prof. dra. Amparo Montañana Casani (Universitat Jaume I), Periculum est emptoris I. 3, 23 (24), 3; dr hab. Magdalena Sitek (prof. UWM), Commercium iure gentium commune esse debet; dra. Andrea Planchadell Gargallo (Universitat Jaume I), The European order for payment procedure. A true way of revitalizing the economy; dr hab. Jerzy Krzynówek (prof. UWM), References to the principle nemo sibi ipsum causam possessionis mutare potest in the judicial decisions of the Polish courts (on selected exemples); dr Przemysław Kubiak (Uniwersytet Łódzki), Some remarks about origins of ignorantia facti non nocet in Roman Law.

Warto odnotować, że po zakończeniu pierwszej części obrad prelegenci mieli okazję obserwować zmagania studentów olsztyńskiego Wydziału Prawa i Administracji, którzy brali udział w finale konkursu wiedzy z prawa rzymskiego. 
Obradom drugiej sesji przewodniczyła prof. dra. Carmen Lázaro Guillamón, a w jej trakcie wygłoszone zostały następujące referaty: dr Ewa Sokalska i dr Małgorzata Augustyniak (UWM), The tradition of ADR (Alternative Dispute Resolution) as an alternative form of justice in the American legal culture; ks. dr Piotr Sadowski (Uniwersytet Opolski), L'impedimento della cognazione nel diritto matrimoniale romano e canonico; dr Krzysztof Szczygielski (Uniwersytet w Białymstoku), The principle ius civile vigilantibus scriptum est in the judicial decisions of the Constitutional Tribunal and the Supreme Court; dr Sławomir Kursa (Szkoła Wyższa Psychologii Społecznej w Warszawie), Roman rule nemo pro parte testatus... and its application in Polish law; dr Aldona Jurewicz (UWM), Commorientes. Ein Versuch der dogmatischen Umschreibung eines Rechtsinstitutes im polnischen $\mathrm{Zi}$ vilrechtsystem; mgr Maria Jasińska (SWPS w Warszawie), Actio Pauliana-today and in the past-regulations in Polish Civil Code; dr Adam Świętoń (UWM), Vanae voces populi non sunt audiendae. Court under the pressure of the vox populi.

Podkreślić należy, iż wystąpienia prelegentów były przedmiotem ożywionej dyskusji prowadzonej po każdej sesji, co dowodzi trafności wyboru tematu olsztyńskiej konferencji. Organizatorzy zapewnili, iż w przyszłości planują kolejne spotkania naukowców z Polski i Hiszpanii. 